\title{
PREDIKSI NILAI TUKAR DOLLAR (USD) KE RUPIAH (IDR) MENGGUNAKAN ARTIFICIAL NEURAL NETWORK
}

\author{
Ahmad Saparudin, Tiya Maulidina \\ Fakultas Sains dan Teknologi, Universitas Jambi \\ email: ahmadsafarudinmsman2@gmail.com
}

\begin{abstract}
In the world of business, especially investment, knowing the exchange rate of the USD to IDR or vice versa is a very important thing. In this study the prediction of the dollar to rupiah exchange rate was made for March 28, 2019 - April 30, 2019 (except Saturday and Sunday) using artificial neural networks (ANN). The results of this study are system models that can be trained and reused to predict another time series data. After doing this research, it is known that there will be a decrease in the dollar exchange rate to the rupiah on the date mentioned above.
\end{abstract}

Keywords: data mining, forecasting, exchange rate, artificial neural network.

\section{PENDAHULUAN}

Data time series atau data runtun waktu didefinisikan sebagai koleksi hasil pengukuran suatu variabel data yang diambil dalam suatu selang waktu tertentu dan dengan interval pengambilan yang tetap. Himpunan data ini dapat dikomposisikan dalam komponenkomponennya yang meliputi tren, seasonality (pola berdasar musim/rentang waktu tertentu) dan random noise (Brockwell \& Richard, 1987). Tren secara umum dedefinisikan sebagai naik atau atau turunnya nilai data, seasonality mengacu kepada pola yang terjadi dalam rentang waktu tertentu, sedangkan random noise mengacu kepada tidak adanya pola karena adanya gangguan pada saat pengukuran / pengambilan data (Kneer, 2004). Salah satu contoh dari data time series adalah nilai tukar rupiah (kurs).

Dalam tulisannya, Anwary (2011) memaparkan bahwa nilai tukar mata uang suatu negara merupakan salah satu indikator penting dalam suatu perekonomian. Nilai tukar juga mempunyai implikasi yang luas, baik dalam konteks ekonomi domestik maupun internasional, mengingat hampir semua negara di dunia melakukan transaksi internasional. Valuta asing yang sering disebut dengan akronim valas pada dasarnya adalah mata uang asing (foreign currencies). Dalam pandangan awam semua valuta asing dapat digunakan sebagai alat pembayaran luar negeri. Namun hanya mata uang tertentu yang dapat digunakan sebagai mata uang untuk membayar transaksi internasional. Persoalan yang sangat penting diperhatikan dalam masalah valuta asing ini adalah Kurs (exchange rate).
Dalam dunia bisnis khususnya investasi, ketidakstabilan exchange rate dari waktu ke waktu akan menyebabkan ketidakstabilan harga saham. Ketidakstabilan dari harga saham secara langsung akan menyebabkan keraguan bagi para investor. Persoalan ini dapat diatasi apabila para investor mengetahui prakiraan harga saham di waktu yang akan datang (forcasting).

Berdasarkan latar belakang diatas, dilandasinya penulisan ini guna melakukan forcasting nilai tukar dollar terhadap rupiah menggunakan artificial neural network. Hasil dari penelitian ini yang berupa prakiraan harga nilai tukar dollar terhadap rupiah untuk tanggal 28 Maret 2019 - 30 April 2019 diharapkan dapat dijadikan perimbangan bagi investor dalam menginvestasikan sahamnya.

\section{TINJAUAN PUSTAKA}

\subsection{Forcasting}

Menurut Indrajit dan Djokopranoto (2003) forcasting adalah kegiatan yang berhubungan dengan meramalkan atau memproyeksikan hal-hal yang terjadi dimasa lampau ke masa depan. Pengertian lain oleh Heizer dan Render (2006) forcasting adalah seni dan ilmu untuk memperkirakan kejadian dimasa depan. Hal ini dapat dilakukan dengan melibatkan pengambilan data masa lalu dan menempatkannya ke masa yang akan datang dengan suatu bentuk model matematis. Bisa juga merupakan prediksi intuisi yang bersifat subjektif, atau bisa juga dengan menggunakan kombinasi.

Forecasting atau ramalan yang dilakukan pada umumnya akan berdasarkan data yang 
terdapat dimasa lampau yang dianalisis dengan mengunakan metode-metode tertentu. Forecasting diupayakan dibuat dapat meminimumkan pengaruh ketidakpastian tersebut, dengan kata lain bertujuan mendapatkan ramalan yang bisa meminimumkan kesalahan meramal (forecast error) yang biasanya diukur dengan Mean Absolute Deviation, Absolute Error, dan lain sebagainya (Subagyo, 1986). Menurut Ruamiana, et al. (2018) dalam dunia usaha sangat penting diperlukan hal-hal yang terjadi dimasa depan sebagai dasar untuk pengambilan keputusan. Peramalan adalah seni dan ilmu memprediksi peristiwa-peristiwa masa depan.

Jenis peramalan dapat dibedakan menjadi beberapa tipe. Peramalan dibagi menjadi 3 macam yaitu (Ruamiana, et al., 2018):

\section{Peramalan ekonomi}

Peramalan ekonomi menjelaskan siklus bisnis dengan memprediksi tingkat inflasi, ketersediaan uang, dana yang dibutuhkan untuk membangun perumahan dan indikator perencanaan lainnya.

2. Peramalan teknologi

Peramalan teknologi memperhatikan tingkat kemajuan teknologi yang dapat meluncurkan produk baru yang menarik, yang membutuhkan pabrik dan peralatan baru.

3. Peramalan permintaan

Peramalan permintaan adalah proyeksi permintaan untuk produk atau layanan suatu perusahaan.

Ruamiana, et al. (2018) juga mengutarakan bahwa peramalan dapat diklasifikasikan berdasarkan horizon waktu masa depan yang dicakupnya. Dalam hubungannya dengan horizon waktu peramalan terbagi atas beberapa kategori, yaitu:

1. Ramalan jangka pendek (short-range forecast)

Mencakup masa depan yang dekat (immediate future) dan memperhatikan kegiatan harian suatu perusahaan bisnis, seperti permintaan harian atau kebutuhan sumber daya harian.

2. Ramalan jangka menengah (mediumrange forecast)

Mencakup jangka waktu satu atau dua bulan sampai satu tahun. Ramalan jangka waktu ini umumnya lebih berkaitan dengan rencana produksi tahunan dan akan mencerminkan hal-hal seperti puncak dan lembah dalam suatu permintaan dan kebutuhan untuk menjamin adanya tambahan untuk sumber daya untuk tahun berikutnya.

3. Ramalan jangka panjang (long-range forecast)

Mencakup periode yang lebih lama dari satu atau dua tahun. Ramalan ini berkaitan dengan usaha manajemen untuk merencanakan produk baru untuk pasar yang berubah, membangun fasilitas baru, atau menjamin adanya pembiayaan jangka panjang.

\subsection{Artificial Neural Network}

Menurut Dessy \& Afrianto (2012) artificial neural network (ANN) merupakan suatu sistem pemrosesan informasi yang mempunyai karakteristik menyerupai jaringan saraf biologi (JSB). ANN tercipta sebagai suatu generalisasi model matematis dari pemahaman manusia (human cognition) yang didasarkan atas asumsi sebagai berikut:

1. Pemrosesan informasi terjadi pada elemen sederhana yang disebut neuron.

2. Sinyal mengalir diantara sel saraf/neuron melalui suatu sambungan penghubung.

3. Setiap sambungan penghubung memiliki bobot yang bersesuaian. Bobot ini akan digunakan untuk menggandakan atau mengalikan sinyal yang dikirim melaluinya.

4. Setiap sel saraf akan menerapkan fungsi aktivasi terhadap sinyal hasil penjumlahan berbobot yang masuk kepadanya untuk menentukan sinyal keluarannya.

Dessy \& Afrianto (2012) mengutarakan model struktur neuron jaringan saraf tiruan dijelaskan pada Gambar 2 dan Gambar 3

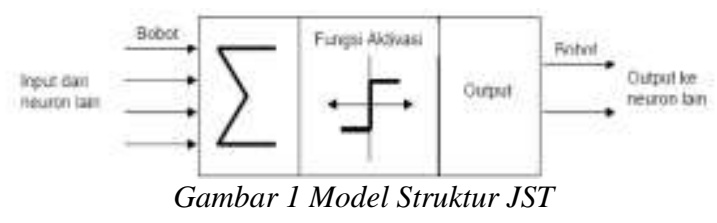




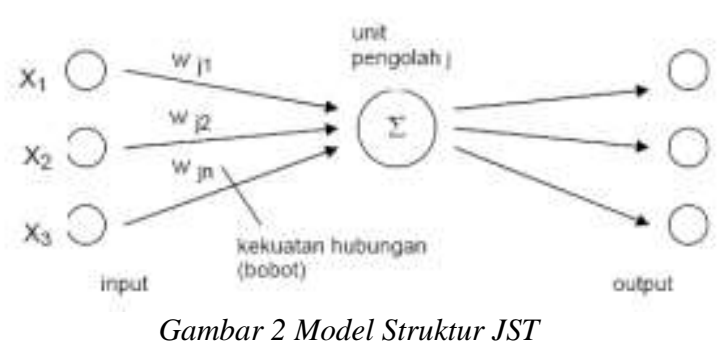

Jaringan saraf tiruan dapat belajar dari pengalaman, melakukan generalisasi atas contoh-contoh yang diperolehnya dan mengabstraksi karakteristik esensial masukan bahkan untuk data yang tidak relevan. Algoritma untuk JST beroperasi secara langsung dengan angka sehingga data yang tidak numerik harus diubah menjadi data numerik. JST tidak diprogram untuk menghasilkan keluaran tertentu. Semua keluaran atau kesimpulan yang ditarik oleh jaringan didasarkan pada pengalamannya selama mengikuti proses pembelajaran. Pada proses pembelajaran, ke dalam JST dimasukkan pola-pola masukan (dan keluaran) lalu jaringan akan diajari untuk memberikan jawaban yang bisa diterima (Dessy \& Afrianto, 2012). Pada dasarnya karakteristik JST ditentukan oleh:

1. Pola hubungan antar neuron (disebut arsitektur jaringan);

2. Metode dilakukannya penentuan bobotbobot sambungan (disebut dengan pelatihan atau proses belajar jaringan); serta

3. Fungsi aktivasi.

Menurut Dessy \& Afrianto (2012) faktor terpenting dalam menentukan kelakuan suatu neuron adalah fungsi aktivasi dan pola bobotnya. Umumnya neuron-neuron yang terletak pada lapisan yang sama akan memiliki keadaan yang sama sehingga pada setiap lapisan yang sama neuron-neuron memiliki fungsi aktivasi yang sama. Bila neuron-neuron pada suatu lapisan (misal lapisan tersembunyi) akan dihubungkan dengan neuron- neuron pada lapisan lain (misal lapisan keluaran) maka setiap neuron pada lapisan tersebut (lapisan tersembunyi) juga harus dihubungkan dengan setiap neuron pada lapisan lainnya (lapisan keluaran). Terdapat 3 macam arsitektur JST, yaitu:

1. Jaringan dengan lapisan tunggal (single layer net)
Jaringan ini hanya memiliki 1 lapisan dengan bobot-bobot terhubung. Jaringan ini hanya menerima masukan kemudian secara langsung akan mengolahnya menjadi keluaran tanpa harus melalui lapisan tersembunyi. Pada gambar berikut neuronneuron pada kedua lapisan saling berhubungan. Seberapa besar hubungan antara 2 neuron ditentukan oleh bobot yang bersesuaian. Semua unit masukan akan dihubungkan dengan setiap unit keluaran seperti terlihat pada Gambar 4 (Dessy \& Afrianto, 2012).

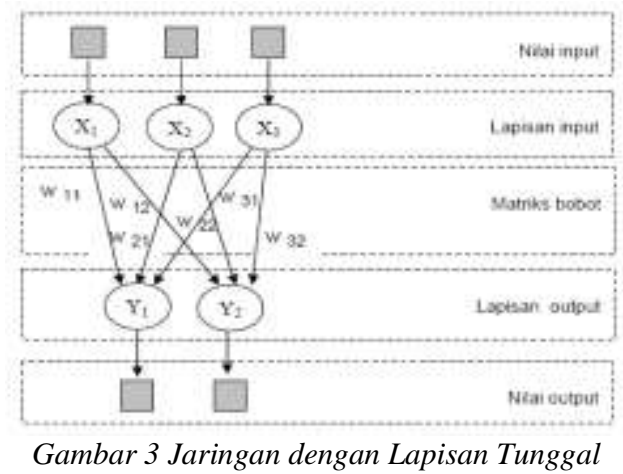

2. Jaringan dengan banyak lapisan (multilayer net)

Jaringan ini memiliki 1 atau lebih lapisan yang terletak diantara lapisan masukan dan lapisan keluaran. Umumnya ada lapisan bobot-bobot yang terletak antara 2 lapisan yang bersebelahan seperti terlihat pada Gambar 5. Jaringan dengan banyak lapisan ini dapat menyelesaikan permasalahan yang lebih sulit daripada lapisan tunggal, tentu saja dengan pembelajaran yang lebih rumit. Pada banyak kasus, pembelajaran pada jaringan dengan banyak lapisan ini lebih sukses dalam menyelesaikan masalah (Dessy \& Afrianto, 2012).

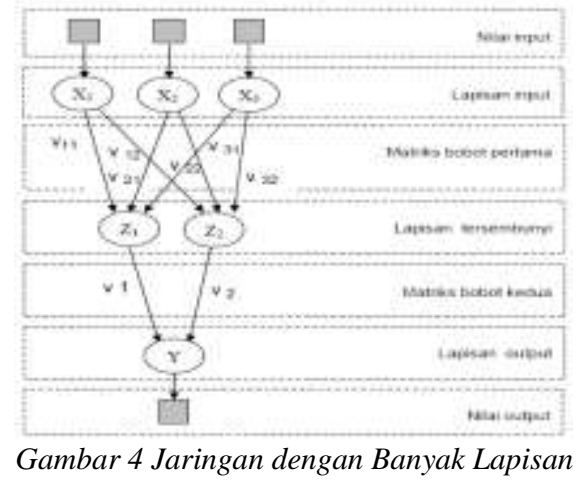

3. Jaringan dengan lapisan kompetitif (competitive layer net) 
Pada jaringan ini sekumpulan neuron bersaing untuk mendapatkan hak menjadi aktif. Umumnya hubungan antar neuron pada lapisan kompetitif ini tidak diperlihatkan pada diagram arsitektur. Gambar 6 menunjukkan salah satu contoh arsitektur jaringan dengan lapisan kompetitif yang memiliki bobot $-\eta$ (Dessy \& Afrianto, 2012).

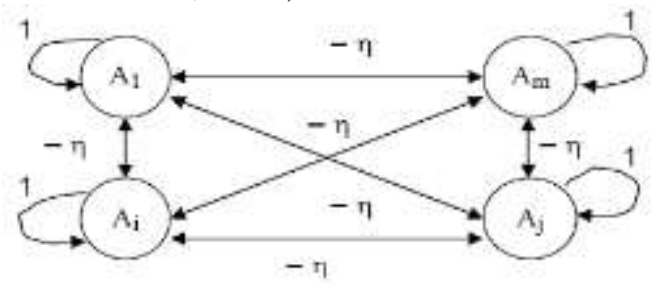

Gambar 5 Jaringan dengan Lapisan Kompetitif

\section{METODOLOGI}

\section{A. Dataset dan Tools}

Dalam penelitian ini dataset yang digunakan data harga nilai tukar mata uang dollar Amerika (USD) dengan rupiah (IDR) yang terhitung mulai 01 Januari 2018 hingga 27 Maret 2019 (kecuali weekend). Data tersebut diperoleh dari perusahaan intevestasi yang memiliki website resmi (https://id.investing.com/currencies/usd-idrhistorical-data). Tools yang digunakan dalam penelitian ini meliputi: plugin pandas, matplotlib, keras, sklearn, numpy, serta math yang ditulis dalam lingkungan bahasa pemrograman Python melalui IDE Jupyter.

B. Prosedur Penelitian/Percobaan

Jalannya penelitian dilakukan dalam tahapan sebagai berikut:
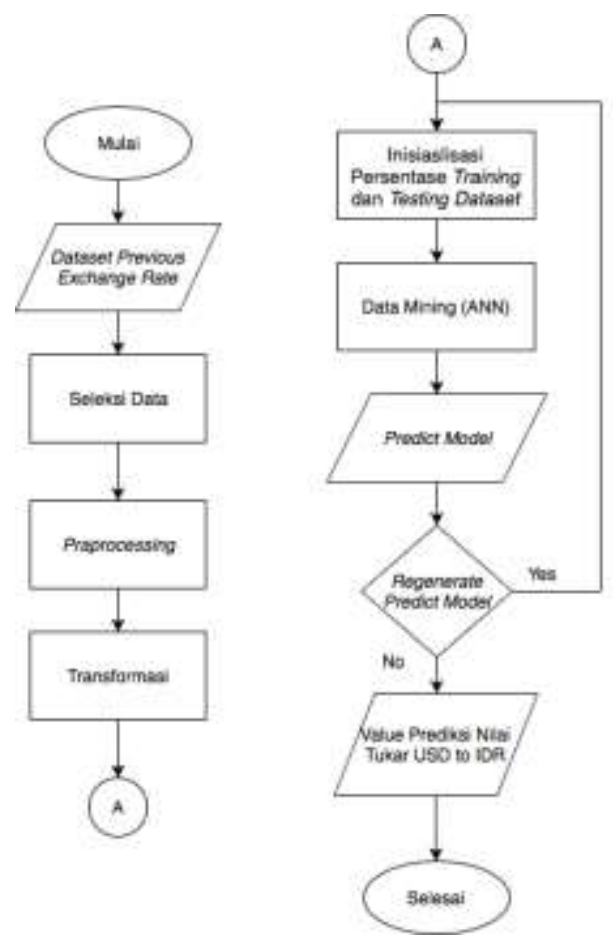

Gambar 6 Flowchart Tahapan Mining

1. Pembersihan dataset (praprocessing)

Data yang digunakan dalam penelitian ini mulanya memiliki 4 field yang meliputi: tanggal, terakhir (harga final), pembukaan (harga tukar awal di tanggal tersebut), tertinggi (harga tertinggi di tanggal tersebut), terendah (harga terendah di hari tersebut), dan perubahan (persentase perubahan harga). Karena dalam penelitian ini terfokus pada prediksi harga nilai tukar dollar ke rupiah di masa yang akan datang (dalam hal ini sebagai percobaan adalah harga tukar dollar di tanggal 28 Maret - 30 April 2019), maka field yang lebih diutamakan atau digunakan adalah field tanggal dan terakhir (harga final). Karena dalam dataset yang digunakan tidak adanya missing value, maka tahapan dilanjutkan ke normalisasi.

2. Normalisasi data

Normalisasi data dalam penelitian ini menggunakan sistem normalisasi scale $0-1$. Normalisasi data tersebut digunakan untuk menyeragamkan data sekaligus untuk mempercepat proses pembentukan neural network (komputasi) yang akan dilakukan nantinya. Dalam normalisasi ini, persamaan yang digunakan adalah:

Dimana:

$$
X^{\prime}=\frac{X-X_{\min }}{X_{\max }-X_{\min }}
$$




$$
\begin{array}{ll}
X^{\prime} & : \text { Nilai hasil (normal) } \\
X & : \text { Nilai saat ini } \\
X_{\min } & : \text { Nilai terkecil dalam field } \mathrm{X} \\
X_{\max } & : \text { Nilai terbesar dalam field } \mathrm{X}
\end{array}
$$

3. Penentuan training dataset dan testing dataset

Dalam penelitian ini percobaan dilakukan sebanyak dua kali. Percobaan pertama akan menggunakan training dataset sebanyak $80 \%$ dari keseluruhan data (284 record) dan testing dataset 20\% dari data awal (71 record).

\section{Pembentukan jaringan neural}

Pembentukan jaringan neural dilakukan menggunakan sistem artificial neural network yang dijalankan pada environment bahasa pemrograman Python dengan sistem pembentukan: 100 iterasi (looping), 1 lapis layer, 1 lapisan LSTM (dengan 8 blok), dan 1 danse layer (untuk menghasilkan 1 output). Mean Sequare Error (MSE) dalam penelitian ini dipilih sebagai metode pengukuran tingkat keakuratan dari prediksi yang dihasilkan.

5. Peninjauan perbandingan harga asli dengan harga prediksi

Hasil prediksi yang dihasilkan oleh sistem dibandingkan dengan harga asli nilai tukar dollar ke rupiah. Apabila hasil prediksi yang diberikan memiliki pola dan value yang mendekati dengan statistic data awal, maka prediksi dilanjutkan ke tujuan utama penelitian (prediksi nilai tukar dollar ke rupiah pada tanggal 28 Maret - 30 April 2019). Namun apabila hasil prediksi yang diberikan melenceng jauh, maka jaringan neural dibentuk kembali dengan jumlah iterasi dinaikkan dari percobaan sebelumnya.

6. Prediksi nilai tukar di masa depan

Prediksi nilai tukar di masa depan dilakukan menggunakan sistem mining (model) yang sebelumnya dibentuk dari hasil pembelajaran (pola nilai tukar dollar ke rupiah dalam training dataset).

\section{HASIL DAN PEMBAHASAN}

A. Hasil

\section{Data Awal}

Dalam penelitian ini data awal terdiri dari 355 record nilai tukar dollar terhadap rupiah yang terhitung mulai tanggal 01 Januari 2018 hingga 27 Maret 2019.

\begin{tabular}{|l|l|}
\hline \multicolumn{1}{|c|}{ Tanggal } & \multicolumn{1}{c|}{ Harga } \\
\hline $01 / 01 / 18$ & 13568 \\
\hline $02 / 01 / 18$ & 13518 \\
\hline $03 / 01 / 18$ & 13478 \\
\hline $04 / 01 / 18$ & 13424 \\
\hline $05 / 01 / 18$ & 13416 \\
\hline $08 / 01 / 18$ & 13427 \\
\hline $09 / 01 / 18$ & 13438 \\
\hline $10 / 01 / 18$ & 13437 \\
\hline $11 / 01 / 18$ & 13400 \\
\hline $12 / 01 / 18$ & 13354 \\
\hline$\ldots$ & $\ldots$ \\
\hline $23 / 03 / 19$ & 14195 \\
\hline
\end{tabular}

Tabel 1 Data Sumber

2. Grafik Nilai Tukar USD to IDR

Berdasarkan pada data sebelumnya (nilai tukar dollar terhadap rupiah pada tanggal 01 Januari 2018 hingga 27 April 2019) maka grafik pergeseran atau perubahan exchange rate USD to IDR dapat digambarkan sebagai berikut:

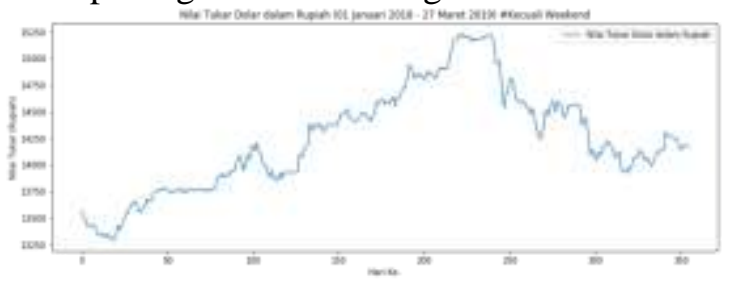

Gambar 7 Grafik Nilai Tukar USD to IDR

3. Data Sebelum dan Sesudah Dinormalisasi

\begin{tabular}{|c|l|}
\hline Index & \multicolumn{1}{|c|}{ Harga } \\
\hline 0 & 13568 \\
\hline 1 & 13518 \\
\hline 2 & 13478 \\
\hline 3 & 13424 \\
\hline 4 & 13416 \\
\hline 5 & 13427 \\
\hline 6 & 13438 \\
\hline 7 & 13437 \\
\hline 8 & 13400 \\
\hline 9 & 13354 \\
\hline$\ldots$ & $\ldots$ \\
\hline 354 & 14195 \\
\hline
\end{tabular}

Tabel 2 Data Sebelum Dinormalisasi

Sebelum dilakukannya proses mining, data terlebih dahulu perlu dilakukan normalisasi guna mempermudah proses data mining. Hasil dari normalisasi yang dimaksudkan yakni: 


\begin{tabular}{|c|l|}
\hline Index & \multicolumn{1}{|c|}{ Harga } \\
\hline 0 & 0.143371 \\
\hline 1 & 0.117678 \\
\hline 2 & 0.097123 \\
\hline 3 & 0.069373 \\
\hline 4 & 0.065262 \\
\hline 5 & 0.070915 \\
\hline 6 & 0.076568 \\
\hline 7 & 0.076054 \\
\hline 8 & 0.057040 \\
\hline 9 & 0.033402 \\
\hline$\ldots$ & $\ldots$ \\
\hline 354 & 0.465570 \\
\hline
\end{tabular}

Tabel 3 Data Setelah Dinormalisasi

4. Perbandingan Hasil Prediksi dengan Data Aslinya

Setelah dilakukan proses mining menggunakan artificial neural network diperoleh model predict yang dapat digunakan untuk melakukan prediksi. Dengan menggunakan model predict yang dihasilkan, adapun grafik perbandingan antara hasil prediksi traning dataset dan testing datasaet dengan data sebenarnya yakni:

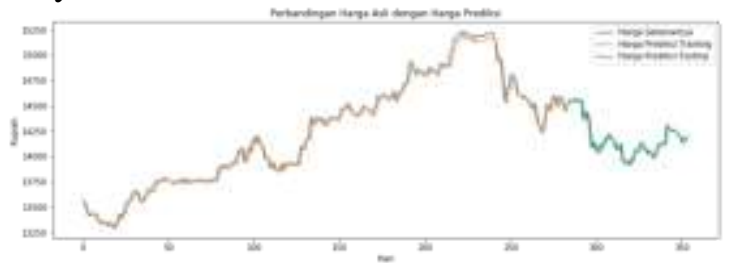

Gambar 8 Grafik Perbandingan Harga Prediksi dengan Harga Asli

\section{Hasil Prediksi Nilai Tukar}

Dengan menggunakan model predict yang dihasilkan pada tahapan sebelumnya, adapun hasil prediksi yang didapatkan untuk hari berikutnya (tanggal 28 Maret 2019 - 01 Maret 2019) yakni sebagai berikut:

a. Tabel Hasil Prediksi

\begin{tabular}{|c|l|}
\hline Index & \multicolumn{1}{|c|}{ Harga } \\
\hline 0 & 0.644028 \\
\hline 1 & 0.635806 \\
\hline 2 & 0.627695 \\
\hline 3 & 0.619686 \\
\hline 4 & 0.611770 \\
\hline$\ldots$ & $\ldots$ \\
\hline 23 & 0.471713 \\
\hline
\end{tabular}

Tabel 4 Hasil Prediksi Sebelum Didenormalisasi

\begin{tabular}{|c|l|}
\hline Index & \multicolumn{1}{|c|}{ Harga } \\
\hline 0 & 14542.278320 \\
\hline 1 & 14526.278320 \\
\hline 2 & 14510.493164 \\
\hline 3 & 14494.908203 \\
\hline 4 & 14479.503906 \\
\hline$\ldots$ & $\ldots$ \\
\hline 23 & 14206.953125 \\
\hline
\end{tabular}

Tabel 5 Hasil Prediksi Setelah Didenormalisasi

b. Grafik Hasil Prediksi

Berdasarkan pada hasil prediksi nilai tukar USD to IDR untuk tanggal 28 Maret 2019 - 30 April 2019 maka data tersebut dapat direfleksikan kedalam grafik berikut:

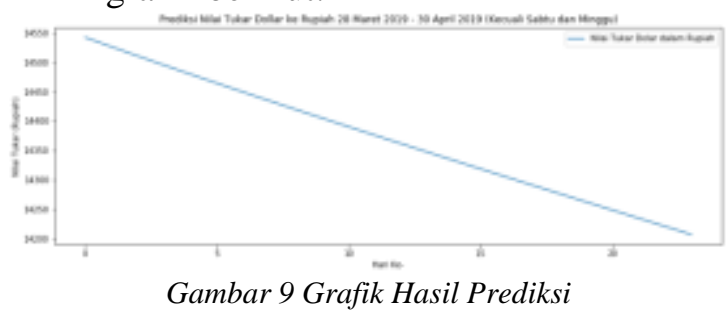

B. Pembahasan

Berdasarkan penelitian yang telah dilakukan terpaparkan bahwa akan terjadi penurunan nilai tukar dollar ke rupiah pada tanggal 28 Maret 2019 - 30 April 2019 (nilai rupiah mengalami kenaikan). Secara ekonomi, hal tersebut akan menyebabkan perubahan harga barang di pasar. Ditinjau dari hasil prediksi dalam penelitian ini, aktivitas pembelian saham internasional atau aktivitas lain yang mengharuskan mengkonversi mata uang IDR ke USD pada 28 Maret 2019 sampai dengan $\quad 30 \quad$ April 2019 kurang direkomendasikan. Sebaliknya, konversi mata uang dari IDR ke USD direkomendasikan.

Berkenaan mengenai model artificial neural network (ANN) yang terbentuk, keakuratan prediksi dari $A N N$ berbanding lurus dengan banyaknya training dataset dan juga jumlah iterasi. Dengan kata lain, semakin banyak training dataset yang digunakan maka semakin tinggi pula tingkat keakuratan prediksi yang dihasilkan. Begitu pula dengan jumlah iterasi, semakin banyak jumlah iterasi maka keakuratan prediksi juga akan semakin meningkat. Training dataset memiliki keterkaitan berbanding lurus dengan keakuratan prediksi disebabkan karena semakin banyak record dalam training dataset (literatur pembelajaran sistem) maka sistem 
juga akan semakin tepat dalam menentukan pola dari data tersebut. Sedangkan hal yang menyebabkan jumlah iterasi dikatakan berbanding lurus dengan keakuratan prediksi sistem yakni dengan banyaknya jumlah iterasi maka sistem akan semakin banyak pula membandingkan hidden layer yang sebelumnya dengan hidden layer baru yang terbentuk akibat penyesuaian dengan dataset, sehingga tingkat kesalahan formula prediksi yang dihasilkan sangat minim.

Menurut penulis, dalam penelitian ini model prediksi yang dihasilkan kuranglah baik, hal ini diutarakan karena hasil pengujian skor MSE menggunakan training dataset dan testing dataset menunjukan angka 53.23 dan 55.79. Walaupun demikian, model prediksi dalam penelitian ini telah didokumentasikan dan diarsipkan, sehingga tingkat kesalahan prediksi dapat diminimalisir dikemudian hari dengan cara mengasah/melatih kembali model prediksi yang digunakan dalam penelitian ini.

\section{KESIMPULAN DAN SARAN}

Dari penelitian yang telah dilakukan, dapat disimpulkan bahwa:

1. Akan terjadi penurunan nilai tukar dollar Amerika (USD) ke rupiah Indonesia (IDR);

2. Penurunan nilai tukar dollar ke rupiah pada tanggal 11 Maret 2019 sampai dengan 15 Maret 2019 adalah Rp14.782,- hingga Rp14.772,-; serta

3. Dalam ANN banyaknya training dataset dan jumlah iterasi berbanding lurus dengan keakuratan prediksi yang dihasilkan oleh sistem.

Untuk penelitian serupa selanjutnya, penulis memberikan saran:

1. Sistem yang dihasilkan dalam penelitian belum memiliki antar muka yang dapat digunakan secara langsung oleh pengguna, sehingga peneliti selanjutnya dapat mengembangkannya menjadi sebuah sisistem informasi berbasis GUI;

2. Peningkatan jumlah iterasi sangat disarankan untuk menambah tingkat keakuratan prediksi yang dihasilkan; dan

3. Sistem yang dihasilkan dalam penelitian ini dapat digunakan dalam penelitian lain guna memprediksi data time series lainnya.

\section{DAFTAR PUSTAKA}

Anwary, A. A., 2011. Prediksi Kurs Rupiah terhadap Dollar Amerika menggunakan Metode Fuzzy Time Series. Semarang: Universitas Diponegoro.

Brockwell, P. J. \& Richard, D., 1987. Times Series: Theory and Methods. New Yorks: Springer Verlag Inc..

Dessy, M. \& Afrianto, I., 2012. Perbandingan Metode Jaringan Saraf Tiruan Backpropagation dan Learning Vector Quantization pada Pengenalan Wajah. Jurnal Komputer dan Informatika (KOMPUTA), 1(45).

Heizer, J. \& Render, B., 2006. Operations Managament. Edisi Ketujuh. Jakarta: Penerbit Salemba Empat.

Indrajit, R. \& Djokopranoto, R., 2003. Manajemen Persediaan. Jakarta: PT Gramedia Widiasaranan Indonesia.

Kneer, C. B. S., 2004. Time Series Prediction Using Neural Networks. Lubbock: Texas Tech University.

Ruamiana, W. B., Nangi, J. \& Tajidun, L., 2018. Aplikasi Forecasting Jumlah Frekuensi Penumpang Pesawat Terbang Lion Air pada Bandar Udara Halu Oleo dengan menggunakan Metode Least Square. semanTIK, 4(1).

Subagyo, 1986. Forecasting Konsep dan Aplikasi. Yogyakarta: BPFE. 